\title{
HUBUNGAN DUKUNGAN KELUARGA DENGAN PENERIMAAN DIRI \\ PASIEN GAGAL GINJAL KRONIK YANG MENJALANI \\ HEMODIALISIS DI RSUD DR. SOEDARSO \\ PONTIANAK
}

\section{(THE RELATIONSHIP OF FAMILY SUPPORT WITH SELF ACCEPTANCE OF CHRONIC RENAL FAILURE PATIENTS ON HEMODIALYSIS AT RSUD DR. SOEDARSO PONTIANAK)}

\author{
Siti Aminah C.W' ${ }^{1}$, Herman², Suhaimi Fauzan² \\ ${ }^{1}$ Mahasiswi Program Studi Keperawatan, Fakultas Kedokteran, Universitas \\ Tanjungpura Pontianak \\ ${ }^{2}$ Dosen Program Studi Keperawatan, Fakultas Kedokteran, Universitas Tanjungpura \\ Pontianak \\ Email: sitiaminah.cewe@gmail.com
}

\begin{abstract}
ABSTRAK
Latar Belakang: Angka penyakit gagal ginjal kronik mengalami kenaikan setiap tahunnya. Gagal ginjal kronik merupakan penyakit yang memerlukan pengobatan dan terapi jangka panjang. Terdapat perubahan-perubahan selama sakit dan menjalani terapi yang dapat menimbulkan masalah pada psikologis pasien. Permasalahan psikologis yang muncul seperti penolakan pada penyakit dan ketidaksiapan menghadapi terapi mempengaruhi penerimaan diri terhadap kondisinya sekarang. Dukungan keluarga merupakan satu diantara faktor untuk meningkatkan penerimaan diri pada individu.

Tujuan: Untuk mengetahui hubungan dukungan keluarga dengan penerimaan diri pasien gagal ginjal kronik yang menjalani hemodialisis di RSUD Dr. Soedarso Pontianak.

Metode: Jenis penelitian ini adalah penelitian kuantitatif dengan desain studi penelitian analitik korelatif dengan pendekatan cross sectional study. Teknik sampling yang digunakan adalah purosive sampling. Jumlah sampel penelitian sebanyak 57 responden. Instrumen yang digunakan adalah kuesioner dukungan keluarga dan kuesioner penerimaan diri, uji statistik yang digunakan adalah uji korelasi spearman.

Hasil: Berdasarkan uji spearman menunjukkan dukungan keluarga dengan penerimaan diri P value $0.000(<0.05)$. Nilai koefisien korelasi sebesar 0,732 menunjukkan bahwa arah korelasi positif dengan kekuatan korelasi kuat.

Kesimpulan: Terdapat hubungan dukungan keluarga dengan penerimaan diri pada pasien gagal ginjal kronik yang menjalani hemodialisis.
\end{abstract}

Kata Kunci: Dukungan keluarga, penerimaan diri, gagal ginjal kronik, hemodialisis 


\begin{abstract}
Background: The rate of chronic renal failure has increased every year. It is a disease that requires long-term treatment and therapy. There are changes during the disease and therapy that can cause psychological problems of the patient. Psychological problems that arise such as resistance to disease and unpreparedness for therapy affects selfacceptance of the current condition. Family support is one of the factors to increase selfacceptance in individual.
\end{abstract}

Objective: To determine the relationship between family support and self-acceptance of chronic renal failure patients on hemodialysis at RSUD Dr. Soedarso Pontianak.

Methods: The type of this research is a quantitative research with a correlative analytic research design with a cross-sectional study approach. The sampling technique used was purposive sampling. The numbers of research sample were 57 respondents. The instruments used were the family support questionnaire and the self-acceptance questionnaire. The statistical test used was the Spearman correlation test.

Results: Based on the Spearman test, it shows family support with self-acceptance Pvalue 0.000 (<0.05). The correlation coefficient value of 0.732 indicates that the direction of the correlation is positive with a strong correlation.

Conclusion: There was a relationship between family support and self-acceptance in chronic renal failure patients on hemodialysis.

Keywords: Family support, self-acceptance, chronic renal failure, hemodialysis

\section{PENDAHULUAN}

Penyakit ginjal merupakan masalah kesehatan masyarakat global dengan prevalensi dan insiden gagal ginjal yang meningkat, prognosis yang buruk dan pembiayaan yang tinggi. Penyakit Gagal Ginjal Kronik (GGK) adalah penyakit yang menyebabkan fungsi dari organ ginjal mengalami penurunan hingga akhirnya tidak mampu melakukan fungsinya dengan baik (Ali, Masi, \& Kallo, 2017). Prevalensi penyakit ginjal kronik meningkat dengan seiringnya peningkatan jumlah penduduk usia lanjut dan kejadian diabetes melitus serta penyakit hipertensi (Kemenkes RI, 2017).

World Health Organization (WHO) menyatakan pada tahun 2013 data pertumbuhan penderita gagal ginjal kronik di dunia meningkat sebesar 50\% dari tahun sebelumnya dan di Amerika angka kejadian gagal ginjal kronik meningkat sebesar 50\% pada tahun 2014 dan pada setiap tahunnya 200.000 orang di Amerika menjalani hemodialisis (Bayhakki \& Hasneli, 2017).

Prevalensi gagal ginjal kronik tahun 2018 di Indonesia pada pasien usia lima belas tahun keatas berdasarkan didiagnosis dokter adalah sebesar 3,8\%. Penderita penyakit gagal ginjal kronik tertinggi pada provinsi Kalimantan Utara. Prevalensi gagal ginjal kronik meningkat pada kelompok umur 65-74 tahun $(8,23 \%)$. Penyakit gagal ginjal diderita pada jenis kelamin laki-laki $(4,17 \%)$ lebih tinggi dari perempuan $(3,52 \%)$ (Riskesdas, 2018).

Prevalensi penyakit gagal ginjal kronik di Kalimantan Barat sebesar $0,43 \%$. Prevalensi penyakit gagal ginjal kronik tertinggi bertempat tinggal di perdesaan sebesar $0,47 \%$. Penderita gagal ginjal kronik tertinggi di Kalimantan Barat berada pada kelompok umur 65-74 tahun (1,24\%). Penyakit gagal ginjal kronik pada jenis kelamin perempuan $(0,50 \%)$ lebih tinggi dari laki-laki $(0,36 \%)$ (Riskesdas, 2018). 
Pasien baru yang menjalani hemodialisis di indonesia dari tahun 2007-2018 berjumlah 66.433 orang dan pasien aktif yang menjalani hemodialisis di indonesia berjumlah 132.142 orang. Pasien baru yang menjalani hemodialisis pada tahun 2018 mengalami kenaikan sebanyak 35.602 orang dan jumlah pasien meningkat pada setiap tahunnya. Jumlah kematian pasien hemodialisis tahun 2018 di Indonesia sebanyak $42 \%$ dengan penyakit penyerta tertinggi adalah penyakit kardiovaskuler (PENEFRI, 2018).

Dalam menentukan pilihan untuk memperpanjang usia harapan hidup bukanlah hal yang mudah bagi individu penderita gagal ginjal. Memilih untuk tidak menjalani transplantasi maka selama hidupnya akan bergantung pada alat dialisa untuk mengganti fungsi ginjalnya. ketergantungan pada mesin dialisa serta penyesuaian diri terhadap kondisi sakit mengakibatkan terjadinya perubahan dalam kehidupan pasien (Isroin, 2017).

Permasalahan psikologis yang dialami pasien gagal ginjal kronik sudah ditunjukkan dari sejak pertama kali pasien di vonis. Gejala-gejala yang dapat muncul menunjukkan ketidaksiapan pada diri pasien gagal ginjal kronik yang telah mengalami penyakit kronis, sehingga penderita mengalami perubahan hidup yang drastis. Penderita gagal ginjal kronik mengalami perubahan dalam hidup seperti merasa putus asa, merasa tidak berguna, dan menarik diri dari lingkungan sekitar sehingga kualitas hidup pasien dapat menurun (Putri \& Uyu, 2016).

Penerimaan diri pada individu merupakan kemampuan untuk mengesampingkan kekurangan dan kesalahan, rasa malu serta kecemasan. Penerimaan diri terdiri dari beberapa aspek yang dapat mempengaruhi seperti keyakinan untuk mengahadapi permasalahan, perasaan beharga, perasaan ditolak oleh masyarakat, perasaan malu dengan kondisinya, tanggung jawab yang dimiliki, pujian dan kritikan yang diterima oleh pasien, motivasi yang diberikan, dan tidak menyalahkan diri sendiri maupun orang lain atas kondisinya (Rohmah, Wakhid, \& Trimawati, 2018).

Penerimaan diri tidak terlepas oleh dukungan sosial baik dari keluarga ataupun lingkungannya terhadap kondisi pasien gagal ginjal kronik. Dukungan yang diberikan secara terus-menerus dapat memberikan semangat dan merasa diperhatikan oleh keluarga (Sinaga \& Bakara, 2019). Dukungan keluarga adalah sikap, tindakan, dan penerimaan keluarga terhadap penderita yang sedang sakit dan bersifat mendukung anggota keluarga dengan selalu siap menolong dan memberikan bantuan (Ahmalia \& Desriyenti, 2018).

Berdasarkan survey awal yang dilakukan peneliti terhadap 5 orang pasien gagal ginjal yang menjalani hemodilisis dengan jangka waktu 3 bulan sampai 2 tahun di Rumah Sakit Umum Daerah Dr. Soedarso Pontianak, 2 dari 5 orang pasien mengatakan setelah menderita penyakit gagal ginjal pasien merasa sedih, kecewa dan putus asa. Saat menjalani terapi pasien mendapat dukungan oleh keluarga dengan mendapatkan perhatian dan rasa nyaman. Sedangkan pada 3 dari 5 orang pasien mengatakan mulai menerima keadaan penyakitnya sekarang dan mengatakan bahwa penyakitnya adalah ujian dari tuhan yang harus diterima. Pada saat hemodialisis 2 orang pasien mengatakan mendapat dukungan dari istrinya serta didampingi saat melakukan terapi dan 1 orang mendapat dukungan dari istri dan anak-anak tetapi saat melakukan terapi tidak didampingi oleh keluarga.

Berdasarkan uraian diatas peneliti tertarik untuk melakukan penelitian 
mengenai hubungan dukungan keluarga dengan penerimaan diri pasien gagal ginjal kronik yang menjalani hemodialisis di RSUD Dr. Soedarso Pontianak.

\section{METODE}

Penelitian ini merupakan penelitian kuantitatif dengan menggunakan jenis penelitian analitik korelatif. Desain penelitian yang digunakan adalah Cross Sectional. Populasi dalam penelitian ini sebanyak 130 orang pasien yang menjalani hemodialisis di RSUD Dr. Soedarso Pontianak. Teknik pengambilan sampel menggunaan purposive sampling yang merupakan teknik non probability sampling dan rumus yang digunakan untuk menentukan besar sampel menggunakan rumus Slovin sehingga didapatkan sampel sebanyak 57 responden.

Instrumen pada penelitian ini menggunakan kuesioner dukungan keluarga yang terdiri dari 20 pertanyaan yang terbagi atas 4 jenis dukungan yaitu, dukungan instrumental, dukungan informasional, dukungan penilaian dan dukungan emosional dan kuesioner penerimaan diri terdiri dari 36 pertanyaan. Analisa data menggunakan analisa statistik di komputer. Setelah data terkumpul kemudian dilakukan pengelolaan data dengan menggunaan uji Spearman.

\section{HASIL}

\section{Analisa Univariat}

Tabel 1 Distribusi Frekuensi Karakteristik Demografi Pasien Gagal Ginjal Kronik Yang Menjalani Hemodialisis Di RSUD Dr. Soedarso Pontianak tahun, 2020

\begin{tabular}{lcc}
\hline Karakteristik Responden & $(\mathbf{f})$ & $(\%)$ \\
\hline Usia & & \\
$<15$ Tahun & 0 & 0 \\
$15-25$ Tahun & 0 & 0 \\
26 - 45 Tahun & 13 & 22,8 \\
46 - 65 Tahun & 36 & 63,2 \\
$>$ 65 Tahun & 8 & 14,0 \\
Total & 57 & 100,0 \\
\hline
\end{tabular}

\begin{tabular}{|c|c|c|}
\hline \multicolumn{3}{|l|}{ Jenis Kelamin } \\
\hline Laki-Laki & 30 & 52,6 \\
\hline Perempuan & 27 & 47,4 \\
\hline Total & 57 & 100 \\
\hline \multicolumn{3}{|l|}{ Pendidikan } \\
\hline Tidak Sekolah & 3 & 5,3 \\
\hline $\mathrm{SD}$ & 5 & 8,8 \\
\hline SMP & 8 & 14,0 \\
\hline SMA/SMK & 20 & 35,1 \\
\hline Perguruan Tinggi & 21 & 36,8 \\
\hline Total & 57 & 100 \\
\hline \multicolumn{3}{|l|}{ Pekerjaan } \\
\hline Tidak Bekerja & 14 & 26,4 \\
\hline Ibu Rumah Tangga & 19 & 33,3 \\
\hline Buruh atau Petani & 0 & 0 \\
\hline Pegawai Negeri Sipil & 13 & 22,8 \\
\hline Swasta atau Wiraswasta & 11 & 19,3 \\
\hline Total & 57 & 100 \\
\hline \multicolumn{3}{|l|}{ Status Pernikahan } \\
\hline Belum Menikah & 3 & 5,3 \\
\hline Menikah & 54 & 94,7 \\
\hline Total & 57 & 100 \\
\hline \multicolumn{3}{|l|}{ Lama Sakit } \\
\hline$<6$ Bulan & 2 & 3,5 \\
\hline $6-12$ Bulan & 14 & 24,6 \\
\hline $12-24$ Bulan & 14 & 24,6 \\
\hline > 24 Bulan & 27 & 47,4 \\
\hline Total & 57 & 100 \\
\hline \multicolumn{3}{|l|}{ Lama Hemodialisis } \\
\hline$<6$ Bulan & 3 & 5,3 \\
\hline $6-12$ Bulan & 15 & 26,3 \\
\hline $12-24$ Bulan & 13 & 22,8 \\
\hline > 24 Bulan & 26 & 45,6 \\
\hline Total & 57 & 100 \\
\hline
\end{tabular}

Data pada Tabel 1 menunjukkan bahwa mayoritas penderita gagal ginjal kronik yang menjalani hemodialisis berusia diantara 46 - 65 tahun dengan jumlah 36 orang responden $(63,2 \%)$. Selain itu terdapat 13 responden berusia 26 - 45 tahun $(22,8 \%)$ dan 8 responden berusia $>65$ tahun $(14,0 \%)$.

Pada kategori jenis kelamin, responden yang mengisi kuesioner lebih banyak laki-laki dibandingkan perempuan. Hal ini dapat dilihat responden paling banyak adalah laki-laki dengan jumlah sebanyak 30 orang $(52,6 \%)$ dan untuk jenis kelamin perempuan sebanyak 27 orang $(47,4 \%)$.

Pada kategori pendidikan, rata-rata responden memiliki latar belakang pendidikan perguruan tinggi sebanyak 21 
orang $(36,8 \%)$ dan responden paling sedikit berasal dari responden yang tidak sekolah sebanyak 3 orang $(5,3 \%)$.

Pada kategori pekerjaan sebagian besar responden berprofesi sebagai ibu rumah tangga sebanyak 19 orang $(33,3 \%)$ sedangkan responden yang pekerjaan swasta atau wiraswasta memiliki jumlah paling sedikit yaitu 11 orang $(19,3 \%)$.

Pada kategori status pernikahan, sebagian besar responden telah menikah sebanyak 54 orang $(94,7 \%)$. Sedangkan responden yang belum menikah sebanyak 3 orang $(5,3 \%)$.

Pada kategori lama sakit, sebagian besar responden telah mengalami lama sakit >24 bulan sebanyak 27 orang $(47,4 \%)$ sedangkan lama sakit paling sedikit dialami $<6$ bulan sebanyak 2 orang $(3,5 \%)$.

Pada kategori lama hemodilisis, sebagian besar responden menjalani lama hemodialisis $>24$ bulan sebanyak 26 orang $(45,6 \%)$ dan hanya ada 3 orang $(5,3 \%)$ yang menjalani lama hemodialisis $<6$ bulan.

Tabel 2 Distribusi Frekuensi Dukungan Keluarga Yang Menjalani Hemodialisis Di RSUD Dr. Soedarso Pontianak, 2020

\begin{tabular}{lcc}
\hline \multicolumn{1}{c}{ Dukungan } & (f) & $(\boldsymbol{\%})$ \\
\hline Keluarga & & \\
Cukup & 0 & 0 \\
Baik & 21 & 36,8 \\
\hline Total & 36 & 63,2 \\
\hline
\end{tabular}

Data pada tabel 2 menunjukkan bahwa dukungan keluarga yang baik sebanyak 36 responden $(63,2 \%)$ dan pasien yang memiliki dukungan keluarga cukup sebanyak 21 responden $(36,8 \%)$.

Tabel 3 Distribusi Frekuensi Penerimaan Diri Yang Menjalani Hemodialisis Di RSUD Dr. Soedarso Pontianak, 2020

\begin{tabular}{llc}
\hline Penerimaan Diri & (f) & $(\boldsymbol{\%})$ \\
\hline Buruk & 27 & 47,4 \\
Baik & 30 & 52,6 \\
\hline Total & 57 & 100 \\
\hline
\end{tabular}

Data pada tabel 3 menunjukkan bahwa penerimaan diri yang baik sebanyak 30 responden $(52,6 \%)$ dan pasien yang memiliki penerimaan diri yang buruk sebanyak 27 responden $(47,2 \%)$.

\section{Analisa Bivariat}

Tabel 4 Hubungan Dukungan Keluarga Dengan Penerimaan Diri Pasien Gagal Ginjal Kronik Yang Menjalani Hemodialisis Di RSUD Dr. Soedarso Pontianak, 2020

\begin{tabular}{|c|c|c|c|c|}
\hline \multirow[t]{2}{*}{$\begin{array}{c}\text { Dukungan } \\
\text { Keluarga }\end{array}$} & \multicolumn{2}{|c|}{$\begin{array}{c}\text { Penerimaan } \\
\text { Diri }\end{array}$} & \multirow{2}{*}{$\begin{array}{c}\text { Koefi } \\
\text { sien } \\
\text { Korel } \\
\text { asi } \\
\end{array}$} & \multirow[t]{2}{*}{$\begin{array}{c}P- \\
\text { value }\end{array}$} \\
\hline & Buruk & Baik & & \\
\hline Cukup & 20 & 1 & 0,732 & 0,000 \\
\hline Baik & 7 & 29 & & \\
\hline Total & 27 & 30 & & \\
\hline
\end{tabular}

Berdasarkan tabel 4 menunjukkan bahwa hasil uji spearman yang menunjukkan $P$-value $=0,000$ dimana hasil tersebut lebik kecil dari 0,05 $(0,000<0,05)$. Koefisien korelasi menunjukkan angka 0,732 yang berarti memiliki hubungan yang kuat antara dukungan keluarga dengan penerimaan diri. Jadi, dapat disimpulkan terdapat hubungan dukungan keluarga dengan penerimaan diri pada pasien gagal ginjal kronik yang menjalani hemodialisis di RSUD Dr. Soedarso Pontianak.

Pada hasil uji menunjukkan bahwa responden yang memiliki dukungan keluarga yang baik cenderung memiliki penerimaan diri yang baik. Dari 30 responden yang memiliki dukungan kelurga dan penerimaan diri baik terdapat 1 responden yang mendapat dukungan keluarga cukup dengan penerimaan diri baik. Namun dalam penelitian ini terdapat 20 responden dengan dukungan keluarga cukup ternyata memiliki penerimaan diri yang buruk.

\section{PEMBAHASAN \\ Karakteristik Responden Berdasarkan Usia, Jenis Kelamin, Pendidikan,}


Pekerjaan, Status Pernikahan, Lama Sakit dan Lama Hemodialisis

1) Usia

Berdasarkan hasil penelitian bahwa pada responden terbanyak yang mengalami gagal ginjal kronik yang menjalani hemodialisis berasal dari usia 45-65 Tahun sebanyak 36 orang. Hasil penelitian ini didukung penelitian Rizki dan Andina (2017) yang menjelaskan usia terbanyak menderita gagal ginjal berada di usia 56-65 Tahun diakibatkan semakin bertambahnya usia maka semakin berkurang fungsi ginjal serta penurunan kecepatan eksresi glomerulus yang mengakibatkan memburuknya fungsi tubulus. Secara fisiologis peningkatan umur dapat terjadi penurunan fungsi ginjal namun terdapat beberapa faktor yang berisiko dapat menyebabkan kelainan seperti riwayat merokok, minuman keras yang menyebabkan menurunnya fungsi ginjal secara cepat dan dapat menimbulkan berbagai keluhan (Yulianto, Wahyudi, \& Marlinda, 2019).

2) Jenis Kelamin

Berdasarkan hasil penelitian didapatkan responden yang menderita gagal ginjal kronik berjenis kelamin laki-laki sebanyak 30 orang. Penelitian ini sejalan dengan penelitian yang dilakukan Rizki dan Andina (2017) angka jenis kelamin penderita gagal ginjal kronik lebih banyak terjadi pada jenis kelamin laki-laki yaitu 36 orang $(51,4 \%)$ dibanding dengan perempuan sebanyak 34 orang $(48,6 \%)$. Secara klinik jenis kelamin laki-laki lebih berisiko mengalami gagal ginjal kronik dua kali lebih besar dari pada jenis kelamin perempuan. Jenis lakilaki lebih mudah terkena gagal ginjal kronik dibandingkan dengan perempuan. Hal ini dikarenakan perempuan lebih memperhatikan kesehatan dan menjaga pola hidup sehat dibandingkan dengan jenis kelamin laki-laki (Yulianto, Wahyudi, \& Marlinda, 2019).

Beberapa penelitian mengatakan bahwa jenis kelamin tidak memiliki hubungan dengan kualitas hidup pasien hemodialisis. Menurut penelitian Wua et al., (2019) jenis kelamin tidak memiliki hubungan terhadap kualitas hidup pasien hemodialisis. Hal ini terjadi karena responden laki-laki dan perempuan mengatakan selama menjalani terapi hemodialisis tidak terganggu dengan kegiatan sehari-hari meskipun memiliki keterbatasan untuk melakukan aktivitas di luar rumah.

3) Pendidikan

Berdasarkan hasil penelitian tingkat pendidikan responden yang paling banyak memiliki tingkat pendidikan perguruan tinggi sebanyak 21 orang. Penelitian ini sejalan dengan penelitian Kusniawati (2018) sebanyak 37 orang $(63,8 \%)$ pasien gagal ginjal kronik yang menjalani hemodilisis berpendidikan SMA dan Perguruan Tinggi. Tingkat pendidikan dapat mempengaruhi perilaku seseorang dalam meningkatkan dan pemeliharaan kesehatan, perilaku pencegahan penyakit, perilaku pencari pengobatan dan perilaku pemulihan kesehatan.

Penderita yang memiliki pendidikan lebih tinggi akan mempunyai pengetahuan yang lebih luas yang dapat mengontrol dirinya dalam mengatasi masalah yang sedang dihadapi, hal ini dapat membantu individu dalam membuat keputusan. Tingginya tingkat pendidikan yang dimiliki seseorang akan cenderung memiliki prilaku yang positif. Pengetahuan yang lebih luas dapat mengontrol diri dalam mengatasi masalah, memiliki rasa percaya diri, 
berpengalaman mudah mengerti yang dianjurkan petugas kesehatan serta membantu individu untuk membuat keputusannya sendiri (Suparti \& Solikhah, 2016).

4) Pekerjaan

Berdasarkan hasil penelitian menunjukkan Pekerjaan penderita terbanyak pada penelitian ini adalah ibu rumah tangga sebanyak 19 orang. Hasil penelitian ini sejalan dengan penelitian Rizki dan Andina (2017) dimana didapatkan bahwa sebagian besar pekerjaan penderita terbanyak adalah ibu rumah tangga sebanyak 28 orang $(40,0 \%)$. Pada penelitian tersebut menjelaskan bahwa penghasilan yang rendah akan berhubungan dengan pemenuhan kebutuhan hidupnya. Pekerjaan seseorang berpengaruh terhadap pendapatan dan kesejahteraan di dalam keluarga.

Penelitian ini juga didukung oleh penelitian Kusniawati (2018) menjelaskan sebagian besar responden sudah tidak bekerja yaitu sebanyak 45 orang $(77,6 \%)$ sedangkan yang masih aktif bekerja sebanyak 13 orang $(22,4 \%)$. Hal ini diakibatkan kegagalan fungsi pada organ pasien yang menjalani hemodialisis mengalami perubahan pada fisik serta ketidakmampuan melakukan aktivitas atau pekerjaan seperti biasanya dan penderita mengalami ketergantungan terhadap orang lain diakibatkan kelemahan fisik yang dirasakan.

5) Status Pernikahan

Berdasarkan hasil penelitian ini didapatkan bahwa sebagian besar responden telah menikah dengan jumlah 54 responden $(94,7 \%)$. Penelitian ini juga didukung oleh penelitian Kusniawati (2018) sebagian besar responden yang menjalani hemodiaisis sudah menikah yaitu sebayak 53 orang $(91,4 \%)$. Status pernikahan yang dimiliki pada pasien gagal ginjal kronik dapat dijadikan sebagai aspek pendukung. Hal ini dikarenakan dukungan yang diberikan oleh pasangan akan berkontribusi pada kemampuan dalam melakukan adaptasi secara psiko-sosial (Astuti, Anggorowati, \& Kusuma, 2017).

6) Lama Sakit

Berdasarkan Hasil penelitian didapatkan responden terbanyak telah lama sakit gagal ginjal kronik selama $>24$ bulan sebanyak 27 orang $(47,4 \%)$. Penelitian ini sejalan dengan penelitian Damanik (2020) responden yang menderita gaga ginjal kronik paling lama telah menderita seama $>1$ tahun sebanyak 51 orang $(68,0 \%)$. Hal ini diakibatkan penyakit sebelumnya yang dapat mempengaruhi lama menderita gagal ginjal kronik sehingga memperlama penyakit dan fungsi tubuh mengalami penurunan yang dapat mengganggu dalam kehidupan sehari-hari (Kamil, Agustina, \& Wahid, 2018).

7) Lama Hemodialisis

Berdasarkan hasil penelitian didapatkan bahwa responden terbanyak telah lama menjalani hemodialisis selama $>24$ bulan sebanyak 26 orang $(45,6 \%)$. Penelitian ini sejalan dengan penelitian Novitasari (2015) respoden yang menjalani hemodialisis paling lama telah menjalani terapi selama >24 bulan sebanyak 38 orang $(63,3 \%)$.

Penelitian ini juga didukung oleh penelitian Kamil et al., (2018) menunjukkan lama pasien yang menjalani hemodialisis paling banyak pada pasien yang menjalani terapi $>12$ bulan sebanyak 120 orang $(65,2 \%)$. Pasien yang sering menjalani hemodialisis mengalami tingkat stres yang sedang. Hal ini dikarenakan pasien sudah dapat menyesuaikan diri dengan kondisi dan dapat merespon 
dengan baik. Penyesuaian ini berkaitan dengan mekanisme koping dan pengalaman serta penerimaan terhadap penyakit yang diderita (Rahayu, Ramlis, \& Fernando, 2018)

\section{Identifikasi Dukungan Keluarga Pada Pasien Gagal Ginjal Kronik Yang Menjalani Hemodialisis Di RSUD Dr. Soedarso Pontianak}

Berdasarkan hasil penelitian ini didapatkan bahwa responden gagal ginjal kronik yang menjalani hemodialisis di RSUD Dr. Soedarso Pontianak memiliki dukungan keluarga sebagian besar berada pada kategori baik sebanyak 36 orang $(63,2 \%)$. penelitian ini searah dengan penelitian yang dilakukan oleh Kusniawati, (2018) dimana responden dalam penelitian ini memiliki dukungan keluarga yang baik sebanyak 41 orang $(70,7 \%)$. Sejalan dengan penelitian Paath et al., (2020) menunjukkan bahwa dukungan keluarga berada pada kategori baik yaitu sebesar 45 orang $(90 \%)$.

Dukungan keluarga merupakan presepsi pasien hemodialisis mengenai sikap, tindakan, dan penerimaan keluarga terhadap dirinya selama menjalani hemodialisis. Bentuk dukungan keluarga yang diberikan seperti dukungan emosional, dukungan perhargaan, dukungan informasional dan dukungan instrumental. Dukungan keluarga berkaitan erat dalam menunjang kualitas seseorang dalam menjalankan peran serta fungsi sebagai mestinya (Fadlilah, 2019).

Menurut penelitian yang dilakukan oleh Saraswati et al., (2019) Dukungan emosional merupakan dukungan yang paling penting diberikan kepada anggota keluarganya, hal ini dapat memberikan semangat kepada pasien dan dapat memberikan ketenangan. Penelitian yang dilakukan oleh Wiliyanarti dan Muhith (2019) menerangkan bahwa dukungan keluarga terhadap pasien yang menjalani hemodialisis dapat memberikan manfaat dalam menejemen dan penyesuaian terhadap penyakitnya.

Identifikasi Penerimaan Diri Pada Pasien Gagal Ginjal Kronik Yang Menjalani Hemodialisis Di RSUD Dr. Soedarso Pontianak

Berdasarkan hasil penelitian ini didapatkan bahwa responden gagal ginjal kronik yang menjalani hemodialisis di RSUD Dr. Soedarso Pontianak memiliki penerimaan diri sebagian besar berada pada kategori baik sebanyak 30 orang $(52,6 \%)$. Penelitian ini selaras dengan penelitian Purnama (2016) dimana responden yang mempunyai penerimaan diri yang tinggi sebanyak 133 orang $(91,7 \%)$. Hasil ini serupa dengan penelitian Sinaga dan Bakara (2019) nilai rata-rata presentase penerimaan diri pada pasien gagal ginjal kronik dalam kategori cukup secara keseluruhan yaitu $71,42 \%$ yang diartikan sebagian besar pasien gagal ginjal kronik dapat menerima dirinya.

Penelitian yang dilakukan Arham et al., (2017) menjelaskan bahwa penerimaan diri seseorang dapat dipengaruhi oleh faktor internal seperti keyainan positif dan faktor eksternal seperti dukungan sosial dan dukungan keluarga. Selain itu, penelitian ini sejalan dengan penelitian yang dilakukan Purnama (2016), menjelaskan bahwa tingkatan penerimaan diri berbeda-beda pada seseorang yang dapat dipengaruhi oleh beberapa faktor lain seperti usia, latar belakang pendidikan, pola asuh orang tua dan dukungan sosial. Hal serupa juga di dukung oleh penelitian yang dilakukan Siregar dan Rhamayani (2019) yang mana penerimaan diri yang tinggi dapat dipengaruhi karena mendapat dukungan sosial yang baik. Dukungan yang diberikan oleh orang lain dapat membuat seseorang merasa diterima oleh lingkungan dan mampu menerima diri sendiri. 
Menganalisis Dukungan Keluarga Dengan Penerimaan Diri Pasien Gagal Ginjal Kronik Yang Menjalani Hemodialisis

Setelah dilakukan uji statistik menggunakan uji spearman ditemuan nilai $\mathrm{p}$-value $=0,000$, dapat disimpulkan bahwa terdapat hubungan antara dukungan keluarga dengan penerimaan diri pasien gagal ginjal kronik yang menjalani hemodialisis di RSUD Dr. Soedarso Pontianak. Adapun koefisien korelasi menunjukkan angka 0,732 yang berarti memiliki hubungan kuat antara dukungan keluarga dan penerimaan diri. Pada hasil ini menampilkan koefisien korelasi yang positif yaitu 0,732 sehingga kedua variabel tersebut searah, dengan demikian dapat diartikan bahwa semakin tinggi tingkat dukungan keluarga pada seseorang maka semakin tinggi penerimaan diri.

Keluarga merupakan lingkungan sosial yang terdekat dan berpengaruh terhadap perkembangan dan kehidupan secara umum. Sistem sosial di dalam keluarga terdapat hubungan yang paling mempengaruhi dan timbal balik antar anggota (Rahakbauw, 2016).

Dukungan keluarga yang diterima diperoleh dari anggota keluarga (suami, istri, anak dan kerabat), teman dekat maupun relasi. Hal lain yang dilakukan keluarga adalah membantu penderita apabila megalami kesulitan ketika melakukan suatu hal yang dapat mengurangi depresi dan merasa dihargai (Karunia, 2016). Peranan keluarga yang diberikan pada pasien seperti, menjaga dan merawat, mempertahankan, meningkatkan status mental, mengantisipasi perubahan sosial ekonomi serta memberikan motivasi dan memfasilitasi kebutuhan spiritual pada pasien (Widyastuti, Kisid, \& Rosuliana, 2019).

Hasil penelitian ini juga sejalan dengan penelitian Sinaga dan Bakara
(2019), dimana adanya hubungan signifikan antara dukungan sosial dengan penerimaan diri pasien gagal ginjal kronik yang menunjukkan adanya korelasi yang kuat antara dukungan keluarga dengan penerimaan diri. Dukungan sosial yang baik diberikan oleh keluarga ataupun lingkungan sangat penting terhadap kondisi pasien gagal ginjal kronik karena pasien gagal ginjal kronik yang menjalani hemodialisis membutuhkan dukungan dalam proses pengobatan dan terapi hemodialisis yang sedang dijalani.

Searah dengan penelitian Purnama (2016), dimana adanya hubungan positif secara signifikan hubungan sosial dengan penerimaan diri pada penderita penyakit gagal ginjal. Semakin positif dukungan sosial yang diterima oleh penderita gagal ginjal maka semakin tinggi penerimaan diri yang dimilikinya. Hal ini dapat terjadi karena pasien mampu menerima keadaannya dengan sabar dikarenakan support yang diberikan oleh orang yang berada disekitarnya (Isroin, 2017).

Dukungan keluarga berpengaruh penting dalam pelaksanaan pengobatan dan kesehatan mental pada keluarga yang sedang sakit. Dukungan keluarga diwujudkan dengan memberikan perhatian, empati, dorongan, memberikan saran dan memberikan pengetahuan (Anggraeni, Sarwono, \& Sunarmi, 2017).

Pada penelitian ini ditemukan 7 pasien yang memiliki dukungan keluarga yang baik, namun memiliki penerimaan diri yang buruk. Hal ini dapat dipengaruhi oleh faktor pekerjaan dimana 3 dari 7 pasien didapatkan berprofesi sebagai PNS. Penelitian yang dilakukan Rahayu et al., (2019) menunjukkan pasien mengeluh dengan kegiatan rutin hemodialisis yang dapat mengganggu pekerjaan dan aktivitas sehari-hari. Terapi hemodialisis akan mengurangi waktu aktivitas pasien yang dapat menimbulkan konflik pada diri pasien 
atau peran pasien. Keadaan sakit yang dialami dapat menimbulkan tuntutan pada sistem biologis dan psikologis individu dimana stres akan timbul dikarenakan tuntutan yang tergantung dengan keseriusan penyakit dan umur individu tersebut (Rahayu, Ramlis, \& Fernando, 2018).

Selain itu, ditemukan 1 pasien yang memiliki dukungan keluarga yang cukup namun memiliki penerimaan diri yang baik. Dilihat dari lamanya menjalani hemodialisis dimana responden telah menjalani terapi > 24 bulan. Responden yang telah lama menjalani terapi dengan waktu yang lama kemungkinan telah terbiasa dengan kondisi dan lingkungannya. Penelitian yang dilakukan Rustina (2012) dalam Hadi (2015), menyatakan responden yang telah lama menjalani terapi hemodialisis cenderung memiliki tingkat kecemasan yang lebih rendah dibandingkan dengan yang baru. Hal ini disebabkan lamanya menjalani terapi hemodialisis akan meningkatkan seseorang menjadi adaptif dengan terapi dan pasien yang telah lama menjalani terapi kemungkinan sudah dalam fase penerimaan.

Berdasarkan penelitian yang telah dilakukan, bahwa dukungan keluarga yang baik memberikan pengaruh pada penerimaan diri pasien gagal ginjal kronik. Penerimaan diri pada individu dapat dipengaruhi oleh keyakinan, adaptasi terhadap kondisi penyakit dan lama menjalani terapi sehingga dapat meningkatkan seseorang menjadi adaptif terhadap kondisinya. Hasil dari penelitian menunjukkan bahwa antara dukungan keluarga dan penerimaan diri memiliki hubungan yang positif. Hubungan tersebut menyatakan dukungan keluarga dan penerimaan diri berbanding lurus, hal ini ditandai dengan semakin tinggi dukungan keluarga maka semakin tinggi penerimaan diri terhadap penyakitnya.

\section{KESIMPULAN DAN SARAN}

Berdasarkan hasil analisa pada data distribusi frekuensi karakteristik demografi didapatkan rata-rata responden mempunyai usia 46-65 tahun, berjenis kelamin laki-laki, tingkat pendidikan tebanyak ditemukan pada tingkat perguruan tinggi, pekerjaan responden berstatus ibu rumah tangga, status pernikahan terbanyak telah menikah, sedangkan lama sakit dan lama hemodialisis pada responden terbanyak telah menjalani $>24$ bulan.

Sebagian besar responden sebanyak 29 orang responden memiliki dukungan keluarga dan penerimaan diri yang baik. Sedangkan sebanyak 20 orang responden yang memiliki dukungan keluarga yang cukup namun memiliki penerimaan diri yang buruk. Sehingga, hasil penelitian ini dapat disimpulkan bahwa terdapat hubungan dukungan keluarga dengan penerimaan diri pasien gagal ginjal kronik yang menjalani hemodialisis.

Bagi peneliti selanjutnya perlu dilanjutkan penelitian dengan menggunakan faktor-faktor yang berbeda untuk meningkatkan penerimaan diri pasien gagal ginjal kronik yang menjalani hemodialisis. Selain itu perlu mengkaji lebih lanjut mengenai perbedaan dukungan keluarga yang diberikan antara laki-laki dan perempuan dalam penerimaan diri pasien gagal ginjal kronik serta perbedaan dukungan keluarga dari tipe keluarga inti atau besar.

\section{DAFTAR PUSTAKA}

Ahmalia, R., \& Desriyenti. (2018). Hubungan Pengetahuan dan Dukungan Keluarga Dengan Tingkat Kepatuhan Mengikuti Program Pengelolaan Penyakit Kronis (prolanis) di wilayah Kerja Puskesmas Kampung Dalam Kabupaten Padang Pariaman Tahun 2018. Journal Kesehatan 
Prima Nusantara Bukittinggi, 9 (2), 116-123.

Ali, A. R., Masi, G. N., \& Kallo, V. (2017). Perbandingan kualitas hidup Pasien Gagal Ginjal Kronik dengan Comorbid Faktor Diabetes Melitus Dan Hipertensi Di Ruangan Hemodialisa RSUP. Prof. DR. R. D. Kandou Manado. e-Jurnal Keperawatan (e-Kp), 5 (2), 1-9.

Anggraeni, K. N., Sarwono, B., \& Sunarmi. (2017). Hubungan Dukungan Keluarga Dengan Tingkat Depresi Pada Pasien Yang Menjalani Terapi Hemodialisa Di Unit Hemodialisa Rumah Sakit Tentara Dr. Soedjono Magelang. Jurnal Keperawatan Soedirman , 12 (2), 107-119.

Arham, S., Ahmad, A., \& Rifdah. (2017). Penerimaan Diri Pada Mahasiswa Drop Out. Jurnal Psikoislamedia, 2 (1), 1-11.

Astuti, Anggorowati, \& Kusuma. (2017). Self Management Tehadapa Psychososial Adjustment Pasien Penyakit Ginjal Kronis Dengan Hemodialisa. Jurnal Keperawatan Soedirman, 12(3), 181-189.

Bayhakki, \& Hasneli, Y. (2017). Hubungan Lama Menjalani Hemodialisa Dengan InterDialitic Weight Gain (IDWG) Pada Pasien Hemodialisis. JKP, 5 (3), 242-248.

Danamik, V. A. (2020). Hubungan Tingkat Kecemasan Dengan Kualitas Tidur Pasien Yang menjalani Hemodialisis. Jurnal Keperawatan Priority, 3 (1), 4757, ISSN 2614-4719.

Fadlilah, S. (2019). Faktor-Faktor Yang Berhubungan Dengan Kualitas Hidup Pasien Hemodialisis. Jurnal Kesehatan, 10 (2), 284-
290, ISSN 2086-7751, ISSN 2548-5695.

Hadi, S. (2015). Hubungan Lama Menjalani Hemodialisis Dengan Kepatuhan Pembatasan Asan Cairan Pada Pasien Gagal Ginjal kronik Di RS PKU Muhammadiyah Unit II Yoyakarta. Sekolah Ting Ilmu Kesehatan 'Aisyiyah. Yoyakarta.

Isroin, L. (2017). Adaptasi Psikogis Psien Yang Menajalani Hemodialisis. Jurnl EDuNursing, 1(1), 12-21, ISSN : 2549-8207 e-ISSN : 25796127.

Kamil, I., Agustina, R., \& Wahid, A. (2018). Gambaran Tingkat Kecemasan Pasien Gagal Ginjal ronik Yang Menjalani Hemodialisis Di RSUD Ulin Banjarmasin. Dinamika Kesehatan, 9 (2), 366-377.

Karunia, E. (2016). Hubungan Antara Dukungan Keluarga Dengan Kemadirian Activity of aily Living Pascastroke. Jurnal Berkala pidemiologi, 4 (2), 213224,

DOI: 10.20473/jbe.v4i2.2016.213-224.

Kemenkes RI. (2017). INFODATIN Pusat Data Dan Informasi Kementrian Kesehatan RI Situasi Penyakit Ginjal Kronis.

Kusniawati. (2018). Hubungan Kepatuhan Menjalani Hemodialisis dan Dukungan Keluarga Dengan Kualitas Hidup Pasien Gagal Ginjal Kronik Di Ruang Hemodialisa Rumah Sakit Umum Kabupaten Tanggerang. Jurnal Medikes, 5 (2), 206-233.

Novitasari, D. (2015). Hubungan Lama Hemodialisis Dengan Kepatuhan Pembatasan Asupan Cairan Pada Klien Hemodialisis Di RS PKU Muhammadiyah Unit 1 Yogakarta. Skripsi Program Studi Ilmu Keperawatan, Sekolah 
Tinggi Ilmu Kesehatan 'Aisyiyah Yogyakarta.

Paath, C. J., Masi, G., \& Onibala, F. (2020). Study Cross Sectional : Dukungan Keluarga Dengan Kepatuhan Hemodialisa Pada Pasien Gagal Ginjal Krons. Jurnal Keperawatan (JKp), 8 (1), 106-112, ISSN:2302-1152.

PENEFRI. (2018). 11th Report Of Indonesia Rena Registry. Diambil kembali dari Retrieved From htttp://www.indonesiarenalregistr y.org

Purnama, M. Z. (2016). Dukungan Sosial dengan Penerimaan Diri Pada Penderita Gagal Ginjal Kronik. SEMINAR ASEAN (Psychology \& Humanity), 267-276.

Putri, E. T., \& Uyu, Q. S. (2016). Meningkatkan Kesejahteraan Subjektif Pasien Gagal Ginjal Kronis Melalui Terapi Kognitif Perilakuan Religius. Jurnal Intervensi Psikologis, 8 (1), 89108.

Rahakbauw, N. (2016). Dukungan Keluarga Terhadap Keberlangsungan Hidup ODA (Orang Dengan HIV/AIDS). INSANI, 3 (2), 64-82, ISSN 2407 6856.

Rahayu, F., Ramlis, R., \& Fernando, T. (2018). Hubungan Frekuensi Hemodialisis Dengan Tingkat Stress Pada Pasien Gagal Ginjal Kronik Yang Menjalani Hemodialisis . Jurnal Keperawtan Silampari, 1(2), 139153, e-ISSN : 2581-1975.

Rahayu, R., Munawaroh, S., \& Mashudi, S. (2019). Respon Stres Pasien Gagal Ginjal Kronik Yang Menjalani Hemodialisa. Health Sciences Journal, 3 (1), 1-10.

Riskesdas. (2018). Laporan Nasional : Riskesdas 2018. Kementrian
Kesehatan

RI. www.litbang.kemkes.go.id.

Riskesdas. (2018). Laporan Provinsi Kalimantan Barat : Riskesdas 2018. Kementerian Kesehatan RI. www.litbang.kemkes.go.id.

Rizki, F. A., \& Andina, M. (2017). Karakteristik Penderita Hipertensi Dengan Gagal Ginjal Kronik Di Instalasi Penyakit Dalam Rumah Sakit Umum Haji Mdan Tahun 2015. Ibnu Sina Biomedika, 1 (1), 87-96.

Rohmah, A., Wakhid, A., \& Trimawati. (2018). Penerimaan Diri Pasien Gagal Ginjal Kronik Yang Menjalani Hemodialisis. Jurnal Ilmiah permas, 8(2), 131-134, pISSN2089-0834 e-ISSN25498134.

Saraswati, N. L., Antari, N. L., \& Suwartini, N. L. (2019). Hubungan Dukungan Keluarga Dengan Kepatuhan Pembatasan Cairan Pada Pasien Chronic Kidney Disease Yang Menjalani Hemodialisa. Jurnal Kesehatan Bhakti Husada, 10 (1), 45-53, EISSN 2623-1204 P-ISSN 22529462.

Sinaga, R. R., \& Bakara, A. Y. (2019). Hubungan antara Dukungan Sosial Dan Penerimaan Diri Pada Pasien dengan Penyakit Ginjal Kronis. Jurnal Skolastik Keperawatan, 5 (1), 85-94.

Siregar, C. T., \& Rhamayani, M. (2019). Self-Acceptance of Chronic Caused Failure Patients That Have aHemodialysis in Medan. CARING: Indonesian Journal of Nursing Science(IJNS), 1 (1), 1824 . .

Suparti, S., \& Solikhah, U. (2016). Perbedaan Kualitas Hidup Pasien Gagal Ginjal Kronik Ditinjau Dari Tingkat Pendidikan, Frekuensi dan Lama Hemodialisis Di RSUD 
Goeteng Taroenadibrata

Purbalingga. MEDISAINS (Jurnal

Ilmiah Ilmu-Ilmu Kesehatan), 14

(2), 50-58.

Widyastuti, P., Kisid, K. M., \&

Rosuliana, N. E. (2019).

Hubungan dukungan keluarga

dan peerimaan Diri Dengan

Tingkat Kecemasan Pada Pasien

Penyakit Jantung Koroner (PJK)

Di Poli Jantung Rumah Sakit

Biomedika Mataram. Prima, 5

(1), 81-86.

Wiliyanarti, P. F., \& Muhith, A. (2019).

Life Experience Of Chronic

Kidney Disease Undergoing

Hemodialysis Therapy.

NurseLine Journal , 4 (1), 54-60,

p-ISSN 2540-7937 e-ISSN 2541464X.

Wua, T. C., Langi, F. L., \& Kaunang, W.

P. (2019). Kualitas Hidup Pasien

Hemodialisis Di Unit Hemodialisi

Rumah Sakit Umum Pusat Prof.

Dr. R.D. Kandau Manado. Jurnal

KESMAS, 8(7), 127-136,.

Yulianto, A., Wahyudi, Y., \& Marlinda. (2019). Mekanisme Koping Dengan Tingkat Depresi Pada Pasien Gagal Ginjal Kronik Pre Hemodealisa. Jurnal Wacana Kesehatan, 4 (2),436-444 ,e-ISSN 2544-6251. 